https://doi.org/10.48009/2_iis_2009_495-504

\title{
A REVIEW OF INTERNET SHOPPING FACTORS: DO THE TECHNOLOGY ACCEPTANCE MODEL OR THEORY OF REASONED ACTION MODEL APPLY?
}

\author{
Alan R. Peslak, Penn State University, arp14@psu.edu \\ Neelima Bhatnagar, University of Pittsburgh at Johnstown, bhatnagr@pitt.edu
}

\begin{abstract}
Electronic commerce and Internet shopping have exploded in the last decade. At last estimate total electronic Business to Consumer sales amounted to an estimated $\$ 130$ billion in 2006 [8]. This manuscript is a first attempt to test two common theories of behavior and test their applicability to Internet shopping. It is important to understand the factors involved in Internet shopping behavior to maximize productivity and consumer experiences.
\end{abstract}

Internet shopping (IS) is an important form of transacting business exchanges between business and consumers and has become extremely popular among teens and young adults as well as the population at large. Internet shopping offers unique advantages over brick and mortar stores and other forms of commerce but still has not gained complete support among all demographics. The elderly and minorities are less likely to use electronic commerce than other groups. This study reviews Internet shopping (IS) and its use, and attempts to determine factors that influence its success. The Technology Acceptance Model (TAM), based on Davis's work [7], is first tested to model IS behavior. Perceived usefulness was positively associated with intention to use Internet shopping but perceived ease of use was not. This manuscript also explores Internet shopping using the Ajzen and Fishbein [1] model of human behavior known as Theory of Reasoned Action (TRA). Specifically, findings reveal that attitude towards Internet shopping was positively associated with intention to use IS but subjective norm was not.

Generally, the study finds that neither TAM nor TRA models IS behavior, but does find that perceived usefulness and attitude do affect behavioral intention. This study has important implications for researchers to further explore these relationships and for practitioners who can use these findings to influence and popularize an important method of commerce. The two factors which do influence "intention to use" Internet shopping are usefulness and attitude.
Keywords: Technology Acceptance Model, TAM, TRA, Theory of Reasoned Action, Internet shopping, behavior, factor analysis, structural equation modeling

\section{INTRODUCTION}

Electronic commerce and Internet shopping have exploded in the last decade. At last estimate total electronic Business to Consumer sales amounted to an estimated $\$ 130$ billion in 2006 [8]. Internet shopping allows consumers to purchase products and services over the Internet in the comfort of their home or office without the need to visit a brick-and-mortar store. It is particularly appealing to those consumers who seek convenience and speed [37] and do not want to take the time to visit a traditional store [14].

Electronic commerce is a global phenomenon [5]. This is evident in additional body of literature with researchers analyzing Internet shopping behavior in countries such as Taiwan, Greece, Singapore, and Hong Kong. [5, 29, 14, $37,17]$.

Internet shopping (IS) is an important form of transacting business exchanges between business and consumers. It has become extremely popular among teens and young adults as well as the population at large. Internet shopping offers unique advantages over brick and mortar stores and other forms of commerce, but still has not gained complete support among all demographics.

\section{MOTIVATION FOR THE STUDY}

Internet shopping has been accepted and embraced by the teen and young adult population. But the general and elderly population has been much slower to adapt to the technology. In January $200980 \%$ of all Internet users 18-32 used the Internet for shopping while less than $50 \%$ of older Americans shop online [16]. 
There are specific advantages to Internet shopping, which are not being reaped due to lower adoption, such as easier price comparison and direct delivery. This study explores the factors associated with Internet shopping behavior and intentions and attempts to determine the significant variables associated with higher IS behavior.

\section{Technology Acceptance Model}

One of the most important models for understanding adoption of information technology is the Technology Acceptance Model (TAM). The model was first proposed by Davis in 1989 and includes two key factors, perceived usefulness and perceived ease of use that are proposed to influence acceptance of a technology. According to Davis [7] perceived usefulness is defined as "the degree to which a person believes that using a particular system would enhance his or her job performance". Others have extended this definition to include overall task performance [26, 10, 28].

Again according to Davis [6] perceived ease of use is "the degree to which a person believes that using a particular system would be free of effort". This is generally how easy the system or technology is to use. In an initial model, Davis, Bagozzi, and Warshaw [6] suggested external variables as a key influencing variable but later Venkatesh and Davis [32] have suggested that external variables are mediated by TAM and have not been included in our model. The original Technology Acceptance Model is illustrated in Figure 1 [32]. As noted, our model was used without the external variables.

\section{Figure 1: Technology acceptance model.}

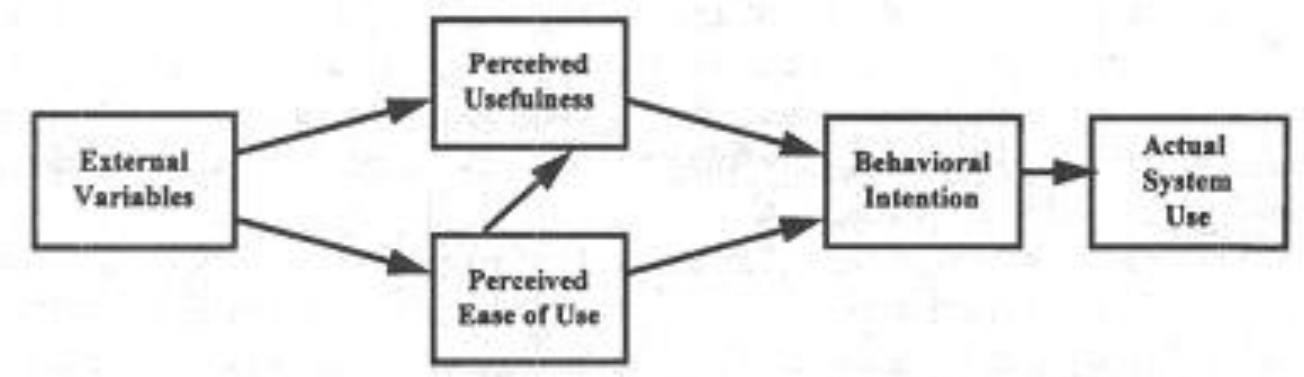

\section{Theory of Reasoned Action}

In order to explore influences on Internet shopping behavior, another common model was selected, Theory of Reasoned Action developed by Ajzen and Fishbein [1]. The model uses four factors: attitude, subjective norm, intention, and behavior. TRA remains an important model for measuring user behavior [25, 34, 4, 30, 35, 19] (Figure 2).

The model is:

Figure 2 Theory of Reasoned Action

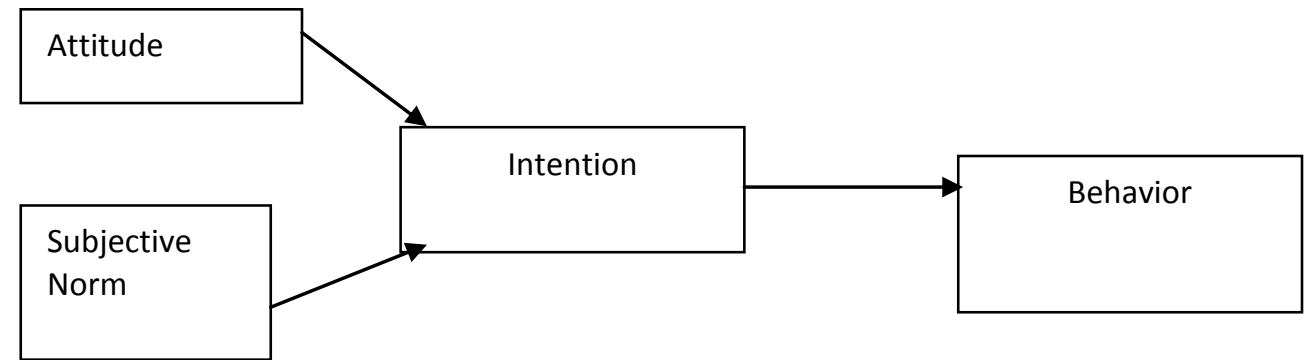


TRA has shown successful application to general consumer information technologies [11, 23], organizational knowledge sharing [18] and "Hsu and $\mathrm{Lu}$ [12] find one important TAM construct -perceived usefulness -- does not directly affect behavioral intention, while the two TRA constructs -- attitude and subjective norms -do." [35]. Intention to use is a common behavioral factor [21, 2]. Actual behavior generally follows intention in a variety of models $[27,2]$.

Definitions of the models factors are as follow:

- Attitude is how we feel about the behavior and is generally measured as a favorable or unfavorable mind-set.

- Subjective norm is defined as how the behavior is viewed by our social circle or those who influence our decisions.

- Intention is defined as the propensity or intention to engage in the behavior.

Behavior is the actual activity itself.

\section{Hypotheses}

In order to determine the applicability of the Technology Acceptance Model or Theory of Reasoned Action to Internet shopping behavior, a series of hypotheses were developed.

The model and factors explored include the original factors of the Davis [7] work, usefulness and ease of use and include two other factors from later work, behavioral intention to use and actual system use [32]. The model used in this study closely follows the works of Qui, Davis, and Gregory [26] as well as Liu, Liao, and Peng, [20]. Due to the multidimensional nature of Internet shopping, the null hypotheses were assumed.

H1: Internet shopping technology will not provide a TAM model fit for behavioral intention and behavior.

H2: Internet shopping technology will not provide a TRA model fit for behavioral intention and behavior.

Given the assumption that neither model would fit the data, individual factors were then hypothesized to influence intention to use IS.
H3: Usefulness of Internet shopping is positively associated with intention to use IS.

H4: Ease of use of Internet shopping is positively associated with use of IS.

H5: Attitude toward Internet shopping is positively associated with intention to use IS.

H6: $\quad$ Subjective norm for Internet shopping is positively associated with usefulness of IS.

\section{METHODOLOGY}

A survey was prepared and pre-tested with a small group of students at a northeastern US university. The survey was modified based on preliminary tests and administered to 128 students at a small southeast US university. The survey was a comprehensive survey of Internet shopping behavior

For each of the TAM factors, survey questions were patterned after prior research. Ease of use, usefulness, and intention factor questions were modeled after Davis [7], intention was based on Venkatesh and Morris [33], and behavior was based on common usage terminology and piracy behavior factor in Woolley and Eining [34]. These survey questions and abbreviations are shown in Table 1. 
Table 1. Survey Questions and Factors

\begin{tabular}{|l|l|l|}
\hline Factor & Abbreviation & Questions/Variables \\
\hline Perceived Ease of use & EA & It is easy to become skilled Internet shopping. \\
\hline Perceived Ease of use & EA & Learning to use Internet shopping is easy. \\
\hline Perceived Ease of use & EA & Internet shopping is clear and understandable \\
\hline Perceived Ease of use & EA & Internet shopping is flexible. \\
\hline Perceived Ease of use & EA & Internet shopping is easy to do. \\
\hline & & \\
\hline Perceived Usefulness & USEF & I find Internet shopping useful. \\
\hline Perceived Usefulness & USEF & I can improve my performance by Internet shopping. \\
\hline Perceived Usefulness & USEF & $\begin{array}{l}\text { I can accomplish things more quickly by Internet } \\
\text { shopping. }\end{array}$ \\
\hline Perceived Usefulness & USEF & I can enhance my effectiveness by Internet shopping \\
\hline Perceived Usefulness & USEF & I can improve my productivity by Internet shopping \\
\hline & & \\
\hline Behavioral Intention & INTENTION & I predict I will use Internet shopping \\
\hline Behavioral Intention & INTENTION & I intend to use Internet shopping \\
\hline Behavioral Intention & INTENTION & I plan to use Internet shopping \\
\hline & & \\
\hline Actual System Use & USE & I plan to use Internet shopping in the future. \\
\hline Actual System Use & USE & I currently use Internet shopping. \\
\hline Actual System Use & USE & I will continue to use Internet shopping. \\
\hline
\end{tabular}

For each of the relevant TRA factors, survey questions modeled prior research. Subjective norm and attitude were based on Fitzmaurice [9]. Intention factor questions were modeled after Ilie, Van Slyke et al. [15], and behavior was based on common usage terminology and piracy behavior factor in Woolley and Eining [34].

The variables needed to test the theory of reasoned action include:

- Attitudes -The survey contained five questions that addressed respondents' attitudes toward Internet shopping. Questions asked if they felt that Internet shopping was useful, worthwhile and valuable.

- Subjective Norm - Subjective norm is defined as a person's "perception that most people who are important to him think he should or should not perform the behavior in question" [1]. The survey contained four questions to measure subjective norm. Two of the questions asked included "Most people who are important to me think I should use Internet shopping" and "People who I listen to could influence me to use Internet shopping."

- Behavioral Intentions - The behavioral intentions are the probability that the subject will use Internet shopping. The survey questions asked the respondents if they plan to use Internet shopping.

- Behavior - behavior is the transmission of intention into action. The questions formulated in the survey asked if the respondents currently use, plan to use or will continue to use Internet shopping. 
Table 2. Survey Questions and Factors

\begin{tabular}{|c|c|c|}
\hline Factor & Abbreviation & Questions/Variables \\
\hline Attitude & ATTITUDE & Internet shopping is good. \\
\hline Attitude & ATTITUDE & Internet shopping is useful. \\
\hline Attitude & ATTITUDE & Internet shopping is worthwhile. \\
\hline Attitude & ATTITUDE & Internet shopping is helpful. \\
\hline Attitude & ATTITUDE & Internet shopping is valuable. \\
\hline Subjective Norm & Subjective Norm & $\begin{array}{l}\text { Most people who are important to me } \\
\text { think I should use Internet shopping. }\end{array}$ \\
\hline Subjective Norm & Subjective Norm & $\begin{array}{l}\text { Close friends and family think it is a } \\
\text { good idea to use Internet shopping }\end{array}$ \\
\hline Subjective Norm & Subjective Norm & $\begin{array}{l}\text { Important people want me to use } \\
\text { Internet shopping }\end{array}$ \\
\hline Subjective Norm & Subjective Norm & $\begin{array}{l}\text { People who I listen to could influence } \\
\text { me to use Internet shopping }\end{array}$ \\
\hline Subjective Norm & Subjective Norm & $\begin{array}{l}\text { Most people who are important to me } \\
\text { think I should use Internet shopping. }\end{array}$ \\
\hline Behavioral Intention & INTENTION & I predict I will use Internet shopping \\
\hline Behavioral Intention & INTENTION & I intend to use Internet shopping \\
\hline Behavioral Intention & INTENTION & I plan to use Internet shopping \\
\hline Actual System Use & BEHAVIOR & $\begin{array}{l}\text { I plan to use Internet shopping in the } \\
\text { future. }\end{array}$ \\
\hline Actual System Use & BEHAVIOR & I currently use Internet shopping. \\
\hline Actual System Use & BEHAVIOR & $\begin{array}{l}\text { I will continue to use Internet } \\
\text { shopping. }\end{array}$ \\
\hline
\end{tabular}

The overall demographics of the group reflected the student population with $96 \%$ of the participants between the ages of 18 and 24. The gender mix was slightly skewed with a $64 \%$ female participation.

The questions measured a five point Likert scale with level of agreement from 1 = strongly agree to $5=$ strongly disagree.

SPSS 16 and AMOS 16 were used to analyze the data and test the proposed hypotheses. Factor analysis and scale reliability as well as structural equation modeling were conducted similar to Wooley and Eining [34], and Moore [22].

\section{RESULTS}

Confirmatory factor analysis and scale reliability testing was used to determine the factors used in the model. All the factors were confirmed with one component determined and eigenvalues over 1.0 which is generally seen as the level of acceptability [22]. The five Ease of use questions resulted in one component with an eigenvalue over 1.0 at 3.264. The component matrix elements all were above .5 (minimum acceptable, [22]) and scale reliability provided a Cronbach's alpha of .857 , well above the minimum acceptable of .7 [24]. The four Attitude questions resulted in one component with an eigenvalue over 1.0 at 3.583. The component matrix elements all were above .5 (minimum acceptable, [22] and scale reliability provided a Cronbach's alpha of .899, well above the minimum acceptable of .7 [24]. The four Subjective norm questions resulted in one component with an eigenvalue over 1.0 at 2.688. The component matrix elements all were above .5 (minimum acceptable, [22]) and scale reliability provided a Cronbach's alpha of .835 , well above the minimum acceptable of .7 [24]. The five Usefulness questions also resulted in one factor with an eigenvalue over one, at 3.833. All components were over .5 and Cronbach's alpha was .922. As noted, these are all well above minimum levels. Intention and its three variables clearly resulted in one factor with an 
eigenvalue over one, at 2.709. All components were over .5 and Cronbach's alpha was at .946 . These were certainly above minimum levels. Finally, actual behavior was measured by three variables and it demonstrated one factor with an eigenvalue over 1.0, at 2.564. All components were over .5 and Cronbach's alpha was .946. In all cases and by all measures all factors met acceptable levels.

Once the factors were determined, the results were analyzed in AMOS 16.0 to test the hypotheses and develop the model using structural equation modeling (SEM).
The results of the analysis are shown in the tables below.

H1: Internet shopping technology will provide a TAM model fit for behavioral intention and behavior.

Ease of use, as shown was not a significant variable with a $\mathrm{p}$ of .155 . Overall the RMSEA for the TAM model also was .245, well above the maximum acceptable of .08 [31]. The null hypothesis could not be rejected. Hypothesis one was supported. TAM is not a model for Internet shopping

Table 3. TAM Regression Weights: (Group number 1 - Default model)

\begin{tabular}{|c|c|c|c|c|c|c|c|}
\hline & & & Estimate & S.E. & C.R. & $\mathrm{P}$ & Label \\
\hline usef & & & .457 & .089 & 5.127 & $* * *$ & \\
\hline intent & $<--$ & usef & .619 & .083 & 7.503 & $* * *$ & \\
\hline intent & $<-$ & ea & .117 & .083 & 1.421 & .155 & \\
\hline use & $<-$ & intent & .634 & .077 & 8.209 & $* * *$ & \\
\hline
\end{tabular}

Table 4. TAM RMSEA

\begin{tabular}{|l|rrrr|}
\hline Model & RMSEA & LO 90 & HI 90 & PCLOSE \\
\hline Default model & .245 & .135 & .373 & .003 \\
Independence model & .375 & .323 & .429 & .000 \\
\hline
\end{tabular}

$\mathrm{H} 2$ : Internet shopping technology will provide a TRA model fit for behavioral intention and behavior.

Even though all factors were significant in the SEM model (table 5), overall the RMSEA for the
TRA model also was .472 (table 6), well above the maximum acceptable of .08 [31]. Hypothesis two was supported. TRA is not a model for Internet shopping.

Table 5. TRA Regression Weights: (Group number 1 - Default model)

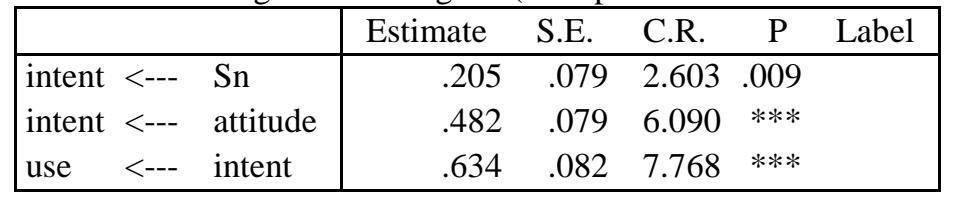

Table 6. TRA RMSEA

\begin{tabular}{|l|rrrr|}
\hline Model & RMSEA & LO 90 & HI 90 & PCLOSE \\
\hline Default model & .472 & .379 & .571 & .000 \\
Independence model & .398 & .347 & .452 & .000 \\
\hline
\end{tabular}

H3: Usefulness of Internet shopping is positively associated with intention to use IS.

All factors were then analyzed in a multiple linear regression analysis. As shown in table 7, usefulness was positively associated with intention to use Internet shopping. This correlation was significant at the $\mathrm{p}<.001$ level. The coefficient was .496. Usefulness of Internet shopping did have an impact on intention to use IS. H3 was accepted. 
H4: Ease of Use of Internet shopping is positively associated with intention to use IS.

Similarly, ease of use was not found to have a positive and significant correlation with intention to use IS. This association was found to be at $\mathrm{p}<.332$. Ease of use does not have an impact on intention to use IS. Hypothesis 4 was rejected.

H5: Attitude towards Internet shopping is positively associated with Usefulness of IS.
Venkatesh and Davis [32] have proposed an association between ease of use and usefulness. Our study found that attitude did have a significant positive impact on ease of use at $\mathrm{p}<.042$. H5 was accepted.

H6: Subjective norm for Internet shopping is positively associated with use of Internet shopping.

Subjective norm was not associated with Internet shopping intention with $\mathrm{p}<.879$. H6 was rejected.

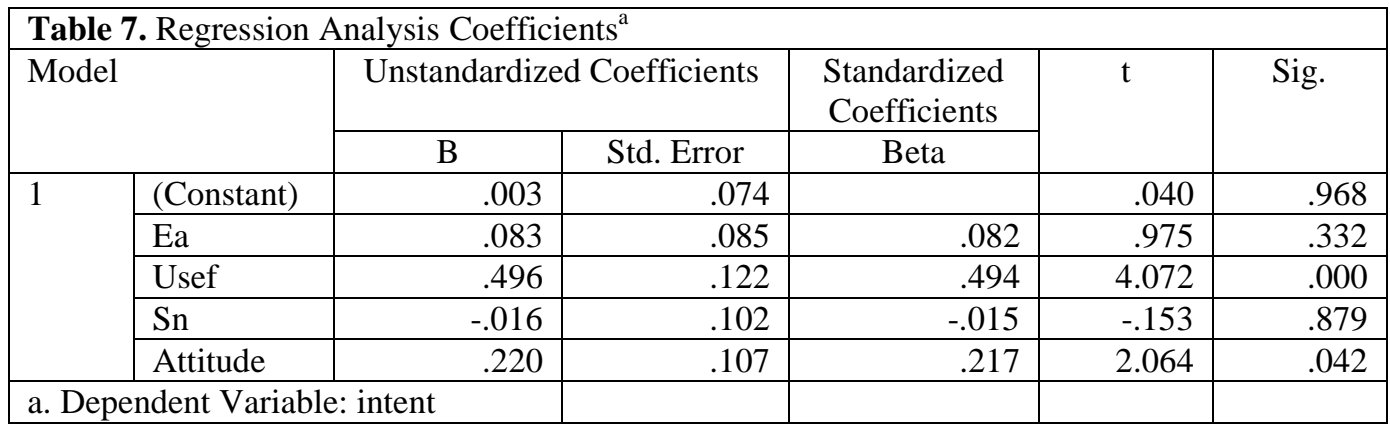

\begin{tabular}{|l|c|c|c|c|}
\hline \multicolumn{5}{|c|}{ Model Summary } \\
\hline $\begin{array}{l}\text { Mode } \\
1\end{array}$ & R & R Square & $\begin{array}{c}\text { Adjusted R } \\
\text { Square }\end{array}$ & $\begin{array}{l}\text { Std. Error of } \\
\text { the Estimate }\end{array}$ \\
\hline 1 & $.697^{\mathrm{a}}$ & .486 & .464 & .73720467 \\
\hline \multicolumn{5}{|l|}{ a. Predictors: (Constant), attitude, ea, sn, usef } \\
\hline
\end{tabular}

\section{LIMITATIONS AND DISCUSSION}

As with any study there are limitations to this study. First, the study examines primarily traditional students at one undergraduate university location. Results ought to be replicated across other locations to confirm the preliminary findings of the study. Also, only students were studied. Though this group does represent a population of significant users, results may be different with non-students or with other age groups. Another limitation is the sample size. Though sizable, the number of participants can be increased to improve reliability. Finally, the study only examines the use of two models of human behavior. Though lack of support for the Technology Acceptance Model and the Theory of Reasoned Action has been demonstrated, there are other models which could be tested.

\section{IMPLICATIONS AND DISCUSSION}

Overall, it has been demonstrated that neither the Technology Acceptance Model nor the Theory of Reasoned Action models can serve as a model for Internet shopping behavior. Research has shown that Internet shopping provides exclusive advantages over traditional shopping. But, Internet shopping is used much less frequently in some cases. Understanding the factors associated with intention and behavior associated with Internet shopping can focus efforts to increase Internet shopping usage.

First, it was shown that intention to use Internet shopping is positively and significantly affected by perceived usefulness of Internet shopping. It has been suggested that use of a technology can be improved if users are educated about the benefits of the technology. [36, 3]. Education in the media or in schools on the benefits and advantages of Internet shopping can allow 
greater use of this technology and improve overall communications. As a result, significant positive cost and productivity improvements for businesses and individuals are possible.

The second finding is that attitude is significantly and positively associated with intention to use IS. Efforts to improve attitude such as training, education, and safety efforts can lead to higher rates of use.

\section{CONCLUSION}

Overall, this study has provided significant factors that influence and model Internet shopping intention and behavior. We see this as the start of an exploration of ways to increase and improve penetration of this valuable technology. Studies can be developed to confirm these findings with larger and more diverse sample groups, but preliminary findings suggest that Internet shopping does not adhere to the technology acceptance model or the theory of reasoned action but is subject to efforts to improve behavior through attention to the significant influencing factors of attitude, usefulness, and behavioral intention. Overall, this is a fertile research area that deserves further attention.

\section{REFERENCES}

1. Ajzen, I. and Fishbein, M.(1980), Understanding Attitudes and Predicting Social Behavior, Englewood Cliffs, NJ: Prentice-Hall, Inc.

2. Bahmanziari, T., Pearson, M. J., \& Crosby, L. (2003). Is Trust Important in Technology Adoption? A Policy Capturing Approach. The Journal of Computer Information Systems, 43 (4), 46-54.

3. Bang, H.-K., Ellinger, A., Hadjimarcou, J., \& Traichal, P. (n.d.). Consumer Concern, Knowledge, Belief, and Attitude Toward Renewable Energy: An Application of the Reasoned Action Theory. Psychology \& Marketing .

4. Brewer, J., Blake, A., Rankin, S., \& Douglas, L. (1999). Theory of Reasoned Action Predicts Milk Consumption in Women. Journal of the American Domestic Association, 99 (1).
5. Cheng, Julian Ming-Sung, Wang, Edward Shih-Tse, Lin, Julia Ying-Chao and Vivek, Shiri D. (2009). Why do customers utilize the internet as a retailing platform? A view from consumer perceived value. Asia Pacific Journal of Marketing and Logistics, 21(1), 144-160.

6. Davis, F., Bagozzi, R., and Warshaw, P. (1989) User Acceptance of Computer Technology: A Comparison Of Two. Management Science, 35 (8) 982+.

7. Davis, F.D. (1989). Perceived Usefulness, Perceived Ease of Use, and User Acceptance of Information Technology, MIS Quarterly, (13), 319340.

8. E-Commerce Market Size and Trends (2006).

http://www.goecart.com/ecommerce_so lutions_facts.asp

9. Fitzmaurice, J. (2005). Incorporating Consumers' Motivations into the Theory of Reasoned Action. Psychology \& Marketing, 22 (11), 911-929.

10. Halawi and McCarthy (2007) Measuring faculty perceptions of blackboard using the technology acceptance model. Issues in Information Systems, 8(2), 160-165.

11. Hansen, T., Jensen, J., \& Solgaard, H. (2004). Predicting Online Grocery Buying Intention: A Comparison of the Theory of Reasoned Action and the Theory of Planned Behavior. International Journal of Information Management, 24 (6), 539-550.

12. Hsu, Ching-Lung, Lu, Hsi-Peng. (2004). Why do People play on-line games? An extended TAM with social influences and flow experience. Information \& Management, 41(7), 853-868. 
13. Hu, L. and Bentler, P. M. (1999), "Cutoff Criteria for Fit Indexes in Covariance Structure Analysis: Conventional Criteria versus New Alternatives", Structural Equation Modeling, 6(1), 1-55.

14. Hui, Tak-Kee and Wan, David. (2007). Factors affecting Internet shopping behaviour in Singapore: gender and educational differences. International Journal of Consumer Studies, 31(3), 310-316.

15. Ilie, V., Van Slyke, C., Green, G., \& Lou, H. (2005). Gender Difference in Perception and Use of Communication Technologies: A Diffusion of Innovation Approach. Information Resources Management Journal , 18 (3), 13-31.

16. Jones S. and Fox S. (2009). Generations Online in 2009. http://www.pewinternet.org/ /media//Fi les/Reports/2009/PIP_Generations 200 9.pdf

17. Karayanni, Despina A. (2003). Webshoppers and non-shoppers; compatibility, relative advantage and demographics. European Business Review, 15(3), 141-152.

18. Kwok, S. H., \& Gao, S. (2005/2006). Attitude Towards Knowledge Sharing Behavior. The Journal of Computer Information Systems, 46 (2), 45-51.

19. Lee, S.-F., Tsai, Y.-C., \& Jih, W.-J. (2007). An Empirical Examination of Customer Perceptions of Mobile Advertising. Information Resources Management Journal, 19 (4).

20. Liu, Liao, and Peng (2005) Applying The Technology Acceptance Model And Flow Theory To Online ELearning Users' Acceptance Behavior. Issues in Information Systems. 6 (1/2), 175-181

21. Lu, J., Yu, C.-S., \& Liu, C. (2005). Facilitating Conditions, Wireless Trust and Adoption Intention. The Journal of
Computer Information Systems, 46 (1), 17-24.

22. Moore (2000) One road to turnover: An examination of work exhaustion in technology professionals MIS Quarterly, 24(1), 141-167.

23. Njite, D., \& Parsa, H. (2005). Structural Equation Modeling of Factors that Influence Consumer Internet Purchase Intentions of Services. Journal of Services Research, 24 (6), 43-59.

24. Nunnally, J.C. (1978), Psychometric Theory. New York: McGraw-Hill.

25. Pak, H. S. (2000). Relationships Among Attitudes and Subjective Norms: Testing the Theory of Reasoned Action Across Cultures. Communication Studies , 51 (2), 162-175.

26. Qui, Davis and Gregory (2003) Student Attitudes Toward Web-Based Course Management System Features, Issues in Information Systems, 4, 672-678.

27. Riemenschneider, C. K., \& Hargrove, B. C. (2001). Explaining Software Development Tool Use With The Technology Acceptance Model. The Journal of Computer Information Systems, 41 (4), 1-8.

28. Simon and Paper (2007) User Acceptance of Voice Recognition Technology: An Empirical Extension of the Technology Acceptance Model, Journal of Organizational and End User Computing, 19(1), 24-50.

29. So, W.C. May, Wong, T.N. Danny, and Sculli, Domenic. (2005). Factors affecting intentions to purchase via the internet. Industrial Management \& Data Systems, 105(9), 1225-1244.

30. Song, J., \& Kim, Y. J. (2006). Social Influence Process in the Acceptance of a Virtual Community Service. Information Systems Front, 8, 241-152. 
31. Stylianou, A. C., \& Jackson, P. J. (2007). A Comparative Examination of Individual Differences and Beliefs on Technology Usage: Gaugin the Role of IT. The Journal of Computer Information Systems, 47 (4), 11-18.

32. Venkatesh and Davis (1996) A model of the antecedents of perceived ease of use: Development and test, Decision Sciences, 27(3) 451-480.

33. Venkatesh, V. and Morris, M. (2000). Why don't men ever stop to ask for directions? Gender, social influence, and their role in technology acceptance and usage behavior, MIS Quarterly, 24 (1), 115-129.

34. Woolley and Eining (2006) Software Piracy among Accounting Students: A Longitudinal Comparison of Changes and Sensitivity, Journal of Information Systems, 20 (1), 49-63.

35. Wu, J., \& Liu, D. (2007). The Effects of Trust and Enjoyment on Intention to Play Online Games. Journal of Electronic Commerce Research, 8 (2).

36. Xu, Y., \& Paulins, V. A. (2005).

College Students' Attitudes Toward

Shopping Online for Apparel Products:.

Journal of Fashion Marking and

Management, 9 (4).

37. Yu, Tai-Kuei and Wu, Guey-Sen. (2007). Determinants of Internet Shopping Behavior: An Application of Reasoned Behaviour Theory. International Journal of Management, 24(4), 744-762. 